\title{
DETERMINANTS OF NET TRADE CREDIT: \\ A PANEL VAR APPROACH BASED ON INDUSTRY
}

Mara Madaleno, Nicoleta Bărbuţă-Mişu, Fitim Deari*

\begin{abstract}
This paper aims to study the dynamic relationship between dependent variables of trade credit (net trade credit to total assets and net trade credit to sales), and six independent variables (profit margin, liquidity ratio, and the dummies collection, credit, size, and crisis) using panel vector autoregression during the period 2004-2013 considering data from eight European countries. The results indicate that net trade credit is negatively influenced by crises, forcing firms to use it less due to survival effects but imposing higher trade restrictions. Notwithstanding, net trade credit to sales is positively influenced by the liquidity ratio and profit margin, and vice-versa, but has a negative relationship with credit and collection dummies, imposing credit shortenings and forcing reliance on short-term credit. For the overall period, firms seem to have sold more than having bought on credit due to tightening trade credit, an effect of the financial crisis.
\end{abstract}

Keywords: panel vector autoregression, profit margin, liquidity ratio, collection period, credit period, financial crisis

JEL Classification: G30, G32, G01

\section{Introduction}

Trade credit (TC) is created whenever a supplier offers terms that allow the buyer to delay payment of goods already delivered (Cuñat, 2007). TC issued is referred to the firm's basic credit policy choices: whether to extend the credit term or to require cash payment; and, if credit is extended, whether to adopt simple terms or terms with discounts for prompt payment (Ng et al., 1999).

The investment in receivable accounts represents an important proportion of a firm's assets, while TC received is an important source of funds for most firms (Baños-Caballero et al., 2014). Being one of the most important sources of borrowing at an individual firm level, TC has three main differences with respect to other types of corporate debt: suppliers

* Mara Madaleno, GOVCOPP - Research Unit in Governance, Competitiveness and Public Policy and University of Aveiro, Portugal (maramadaleno@ua.pt);

Nicoleta Bărbuță-Mişu, "Dunarea de Jos” University of Galati, Romania (Nicoleta.Barbuta@ugal.ro); Fitim Deari, South East European University, Republic of Macedonia (f.deari@seeu.edu.mk). This work was supported by the SOP IEC, under Grant SMIS-CNSR 815-48745, no. 622/2014. We would also want to acknowledge the use of the code made available by Abrigo \& Love (2015) for panel VAR GMM analysis. This work was also, in part, financially supported by the Research Unit on Governance, Competitiveness and Public Policy - GOVCOPP (project POCI-01-0145FEDER-008540), funded by FEDER funds through COMPETE2020 - Programa Operacional Competitividade e Internacionalização (POCI) - and by national funds through FCT - Fundação para a Ciência e a Tecnologia. Any persistent error or missing's are the authors' entire responsibility. We thank the reviewers and the editor of the Journal whose comments helped us improve the present article.

The article has been equally contributed by all authors. 
lend "in kind", which means they seldom lend cash; in contrast to bonds or loans, TC is frequently not subject to specific, formal contracts between the lender and the borrower; and TC is issued by non-financial firms (Cuñat and Garcia-Appendini, 2012). Usually, small businesses (SMEs) increase TC (both payables and receivables) if bank loan availability improves because SMEs with enhanced credit availability offer more TC to their customers (Tsuruta, 2015).

The TC channel is used by firms to manage growth. Firms that are more vulnerable to financial market imperfections, and therefore are more likely to be financially constrained, rely more on the TC channel to manage growth (Ferrando and Mulier, 2013). In poorly developed financial markets, the borrowing in the form of TC may provide an alternative source of funds for firms (Fisman and Love, 2003). During tight monetary periods, TC operates mainly as a substitute for bank borrowing, while during looser monetary episodes even when the economy is weak, TC and bank loans are dominated by a complementary effect (Yang, 2011).

The aim of this paper is to study the dynamic relationship between net TC and six independent variables (profit margin, liquidity ratio, and the dummies collection, credit, size, and crisis). This paper complements earlier work in finance by showing that net TC is obviously affected by the crisis, by the rationale that the crisis has imposed firms to redefine the TC policy. For the whole analysed period, our results seem to indicate that firms have sold more than having bought on credit, making evident an average positive net TC.

The present article is distinct from previous ones in several different ways. First, by dealing with a larger data set including eight European countries with different contributions with respect to the construction sector, providing the relatively high importance of the construction sector within their economies. Second, by analysing a specific and important economic activity sector, the construction sector. Third, by including as exogenous variable a crisis dummy to account for the financial and economic crisis felt by all these countries during the period 2007-2009.

The construction sector in nearly all EU member states felt a major impact of the economic and financial crisis. According to Eurostat (2015), in 2008-2010, the construction production index in the EU-28 fell by $18.6 \%$. A low level was also reached in March 2013, when output fell by over 9.6\% compared to 2011. Only in 2013-2014, we found a $6.1 \%$ increase in the level of the production index. Moreover, the construction sector accounted for $14.7 \%$ of all firms in the non-financial business economy, employed $9.5 \%$ of its workforce, generated $8 \%$ of its value added, and on average, firms in this sector are smaller than those in the non-financial business economy, as measured by employment levels or value added. Fourth, it differs by using a different econometric approach allowing simultaneous interaction among variables: panel vector autoregressive models (panel VAR). This model allows us to identify and validate the main influencing factors, as well as the relations between them and the dependent variable, offering a regression-type relation, also usable for future forecast. The adopted methodology can uncover all sorts of dynamic or static dependencies among firms or the existence of heterogeneity in coefficients on the variables of different countries/firms. As such, the economic analysis transposes 
the results of econometric analysis into concrete actions and measures that managers can take to ensure future improvement of their economic efficiency.

The work is organized as follows. Section 2 presents a brief literature review while Section 3 presents the data and a description of the variables. Section 4 develops the model and methodology. Section 5 reflects the main results and discussions, and final conclusions are presented in Section 6.

\section{Literature Review}

TC is the subject of many types of research based on reviews of TC literature from micro and macroeconomic perspectives (Seifert et al., 2013). There is no fixed level of accounts receivable and payable that the firm should have. This level is affected by many factors: suppliers' willingness to discriminate prices, information asymmetry between suppliers and customers, market structure, stages of business cycles, and customers' creditworthiness (Altunok, 2012). Usually, both financial and commercial motives explain the credit behavior of firms and suppliers act as financial intermediaries in favor of companies with a limited access to bank credit (Delannay and Weill, 2004).

There are many and diverse motives that lead buyers to take TC: firms with higher access to institutional credit use TC less, in spite of being offered relatively more credit from their suppliers (Petersen and Rajan, 2007). TC is more expensive than institutional finance and gives credence to the theories of information asymmetry of TC (Cuñat and Garcia-Appendini, 2012). Suppliers do not offer more credit to firms that have established relationships with financial institutions, suggesting that suppliers generate their own information about the creditworthiness of their clients, and lends support to theories of information advantage of suppliers over banks (Smith, 1987; Biais and Gollier, 1997; Burkart and Ellingsen, 2004). Suppliers tend to provide liquidity support to growing firms facing financial difficulties (Wilner, 2000; Cuñat, 2007).

TC may emerge as a natural way to reduce costs inherent in a firm's cash management. There are two major theories that motivate TC because of these transaction costs. Firms facing the uncertainty of the time of delivery of the goods may use TC to determine in anticipation when there will be a cash inflow or outflow. A seller facing random cash inflows has incentives to obtain a more predictable stream of cash and better manage his own liquidity (Ferris, 1981). TC can be justified as an efficient way for firms facing cash requirements to minimize liquidity management costs related to excess borrowing or insolvency (Emery, 1984).

Thus, firms with better access to credit offer more TC (Petersen and Rajan, 2007) and larger firms, with better access to alternative internal and external financing and with a lower cost, use less credit from suppliers (Garcia-Teruel and Martinez-Solano, 2010). When lending became less severe, the allocation of lending became more efficient, and the amount of TC extended by private firms declined (Cull et al., 2009). Also, industries with higher dependence on TC financing exhibit higher rates of growth in countries with weaker financial institutions, and most of the effect reported comes from growth in the size of pre-existing firms, consistent with barriers to access TC among young firms (Fisman 
and Love, 2003). A more highly developed financial sector helps firms to better use TC as a short-term financing instrument (Wu et al., 2012). Economic shocks enhance a positive relation between TC used by firms and their probability of insolvency (Bastos and Pindado, 2013).

It is known that firms operating in competitive markets are forced to offer industry credit terms. In effect, SMEs are forced to grant TC despite the costs associated with it, because not granting TC would lose sales, and profitability would decrease (Cheng and Pike, 2003). Also, shorter credit periods than the industry mean reduced firm profitability (Martínez-Sola et al., 2014) and longer credit periods help customers to face liquidity problems, which may facilitate future sales (Hill et al., 2010).

As for the relationship between TC and liquidity, Niskanen and Niskanen (2006) found that firms with a high ratio of current assets to total assets, and firms subject to loan restructurings use more $\mathrm{TC}$. $\mathrm{Ng}$ et al. (1999) argue that $\mathrm{TC}$ is given from firms with high liquidity to firms with low liquidity. The Emery model (1984) suggests that more liquid firms will extend TC as an alternative to invest in marketable securities (Masanori, 2001). Otherwise, a negative relationship between liquidity and extended TC was found by Bougheas et al. (2009) and Peterson and Rajan (1997), arguing that firms react by increasing the credit they grant in an attempt to stem falling sales.

Firm size affects credit extension choices directly by setting limits on the possibilities for economies of scale, but it also impacts indirectly by affecting the firm's access to finance and its bargaining strength suppliers (Wilson and Summers, 2002). Larger firms extend and receive more TC too and from their business partners. Thus, the levels of accounts receivable and accounts payable divided by sales, increase with the size of the firm (Bougheas et al., 2009). That means larger firms, with greater growth opportunities and greater investment in current assets, receive more finance from their suppliers (García-Teruel and MartínezSolano, 2010). Otherwise, Niskanen and Niskanen (2006) found that larger and older firms and firms with strong internal financing are less likely to use TC. Lang and Stulz (1994) find a negative relation between firm size and performance for U.S. companies, whereas Berger and Ofek (1995) found a positive relationship that means larger firms are more profitable and use more TC.

Firms with direct access to capital markets both extend more and receive less TC during a recession (Kohler et al., 2000). Studying the behavior of TC around the time of financial crises Love et al., (2007) found an increase in TC at the peak of financial crises, followed by a subsequent collapse of TC right after crisis events. Tsung-Te and Jian-Hsin (2015) found a significant decrease of the demand/supply-side of TC at the peak of the financial crisis, followed by a subsequent increase of this source of financing after the crisis events. Both large and small firms provide significantly less TC and receive less TC during financial crisis. After the crisis, larger firms still provide significantly less TC to their customers but receive more TC from the suppliers than smaller firms.

In the moment of credit constraints caused by financial crisis, firms with high level of credit receivables postpone payments to suppliers to avoid an increase in their liquidity risk, because they might not receive payments for their sales made on credit, and these 
firms have no other funding source to use. That means, firms prefer to delay collection from their customers, demand long-term TC from their suppliers, present high levels of days-ofsales outstanding and a high probability of insolvency. Firms use more TC, whereas these relations are enhanced during a financial crisis (Bastos and Pindado, 2013). In the periods without crisis, the positive relation between TC use and TC extension is weakened.

Financially stronger firms extend relatively more TC, most likely than financially vulnerable SMEs in the aftermath of the financial crisis (McGuinness and Hogan, 2016). Small firms from all sectors substitute bank financing for TC in crisis periods. But larger firms (in Brazil and Mexico) do not finance with TC in crisis periods due to their better capability to get money from local and foreign capital markets and their improved ability to generate cash internally (Santos et al., 2012).

This study can generate a real contribution to the use of TC considering firms from the construction sector since the model used includes variables which makes it readily applicable to any country, region or continent, whereas a large number of observations can guarantee the relevance and objectivity of the results.

\section{Data and Variables}

Data used in this study were selected and extracted from the Amadeus database and cover the period 2004-2013. The selected firms operate in the construction sector (buildings, bridges and tunnels, other civil engineering projects, roads and railways, underground railways) and are from eight of the EU-28 countries (Belgium, Germany, France, Netherlands, Romania, Bulgaria, Poland and Hungary). These were selected since the average fluctuations of annual growth rates for the construction sector were appropriate.

In our model, we used the following as dependent variables: net trade credit to total assets $(N C 1)$ and net trade credit to sales $(N C 2)$; as independent variables we used liquidity ratio $(L R)$, profit margin $(P M)$, and the dummies credit period $(C R D)$, collection period $(C D)$, size (SIZE) and crises $(C)$. The reasons for selecting $N C 1$ and $N C 2$ as dependent variables are as follows: (i) they are used in many studies, but are correlated with other independent variables: sales change, firm size, inventory stock, retained earnings, short-term debt (Choi and Kim, 2005), or implied borrowing costs, return on investment ratio, early payment weighted average discount, profit to sales ratio, export to sales ratio, company size, trade debt to purchases ratio (Marotta, 2005); (ii) they are the most representative indicators for TC, reflecting the firm position: debtor or creditor for business partners.

$N C 1$ was studied by Choi and Kim (2005), who found that tighter policy induces firms to increase accounts receivable more than accounts payable, resulting in an increase in $N C 1$, but they found no evidence that, upon tighter policy, large firms increase $N C 1$ more than smaller firms do. Yang (2011b) also used NC1 as a dependent variable for testing the crosssectional response to crises; he found that firms with a more vulnerable financial position are more likely to be negatively affected by crises and, in turn, are more likely to cut their 
supply of credit to customers and increase their use of credit from suppliers. Marotta (2005) performed an econometric investigation using NC2 showing that discounts offered have the expected effect of reducing payment delays mostly for customers located abroad, where customary credit periods are shorter and protection of creditors' rights is more effective.

The variables used are presented in Table 1. In this study, creditors mean debts to suppliers and contractors (trade creditors), while debtors mean trade receivables (from clients and customers only).

Table 1 | Definition of variables

\begin{tabular}{|c|c|c|}
\hline Description & Abbreviation & Calculation \\
\hline \multicolumn{3}{|r|}{ Dependent variables } \\
\hline Net trade credit (1) & NC1 & (Debtors - Creditors) / Total assets \\
\hline Net trade credit (2) & NC2 & (Debtors - Creditors) / Sales \\
\hline \multicolumn{3}{|r|}{ Independent variables } \\
\hline Liquidity ratio (x) & LR & (Current assets - Inventories) / Current liabilities \\
\hline Profit margin (\%) & PM & (Profit before tax / Operating revenue) $\times 100$ \\
\hline Credit dummies & CRD & $\begin{array}{l}\text { in days } \\
\text { Short credit period: } 0-60 \text { days }=0 \text {; } \\
\text { Long credit period: } \geq 61=1\end{array}$ \\
\hline Collection dummies & $C D$ & $\begin{array}{l}\text { in days } \\
\text { Short collection period: } 0-60 \text { days }=0 \text {; } \\
\text { Long collection period: } \geq 61=1\end{array}$ \\
\hline Firm size & SIZE & Medium $=0 ;$ Large $=1$ \\
\hline Crises dummies & $\mathrm{C}$ & $2003-2006=0 ; 2007-2009=1 ; 2010-2013=0$ \\
\hline
\end{tabular}

Notes: Collection and credit period are divided into two categories (short and long period) and the financial crisis effect in the period 2004-2013 is divided into two periods: with crises (2007-2009) and without crises (2003-2006 and 2010-2013). A short period in this study is defined if the firm has collected debtors, respectively paid creditors from 0 to 60 days. A long period in this study is defined if the firm has collected debtors, respectively paid creditors from 61 days and above. The firm is defined as medium or large based on the number of employees, i.e., medium is from 50 to 249 ; and large if $\geq 250$.

Source: Amadeus database and authors' calculations.

Table 2 presents that, on average, the selected firms are profitable and liquid. Another important fact is that, on average, the firms have sold more than having purchased on credit. Hence, a positive net TC is evidenced, denoted by the two dependent variables $N C 1$ and $N C 2$. The standard deviation for $N C 2$ is higher due to fluctuations in sales, while total assets evidence fewer variations. 
Table 2 | Summary statistics

\begin{tabular}{|l|c|c|c|c|c|}
\hline Variable & Observation & Mean & Std. Dev. & Min & Max \\
\hline NC1 & 7,779 & 0.070 & 0.195 & -0.944 & 1.000 \\
\hline NC2 & 7,633 & 0.059 & 0.468 & -8.350 & 27.644 \\
\hline LR & 8,417 & 1.398 & 2.355 & 0.054 & 92.592 \\
\hline $\boldsymbol{P M}$ & 8,288 & 5.096 & 8.877 & -93.614 & 100.000 \\
\hline CRD & 8,473 & 0.487 & 0.500 & 0.000 & 1.000 \\
\hline CD & 8,473 & 0.586 & 0.493 & 0.000 & 1.000 \\
\hline SIZE & 7,586 & 0.304 & 0.460 & 0.000 & 1.000 \\
\hline $\boldsymbol{C}$ & 8,473 & 0.319 & 0.466 & 0.000 & 1.000 \\
\hline
\end{tabular}

Note: Variables are defined in Table 1. Net trade credit (1) - NC1; Net trade credit (2) - NC2; Liquidity ratio (x) - LR; Profit margin (\%) - PM; Credit dummies - CRD; Collection dummies - CD; Firm size - SIZE; Crises dummies - C.

Source: Authors' calculations.

The selected firms have older debtors and younger creditors. Moreover, the majority of the observations are from the non-crisis period with $68 \%$, whereas the rest, $32 \%$, are from the crisis period. This is also confirmed by the cross-section of data between collection and credit periods, and crisis effects which show that the majority of our data relies on the non-crisis period. In this period, there are 50\% more observations from older debtors than younger ones, while in the crisis period observations from older debtors are just $24 \%$ compared with younger ones. This fact explains that firms were more careful in selling on credit during the crisis period due to the associated default risk. In the non-crisis period, it seems that firms were more likely to extend the collection period as a function of motivating debtors and thus to increase sales, and the selected firms also used more TC from younger creditors.

From the net trade period perspective, in the non-crisis period, firms used more TC than provided in the short-term period, by opposition to the long-term period. However, in the crisis period, firms provided slightly more TC than used in the short-term period and used slightly more TC than provided in the long-term period.

Both $N C 1$ and $N C 2$ experienced a significant decrease when comparing the noncrisis to the crisis period, indicating that firms made efforts to sell less and purchase more on credit during the crisis period. Moreover, in percentage terms, $P M$ increased much more than $L R$. This is a common problem during crisis times: liquidity vs. profitability.

\section{Model and Methodology: Panel Vector Autoregressive Model}

Panel vector autoregressive (VAR) models have been increasingly used in applied research (Love and Ziccino, 2006; Abrigo and Love, 2015) given that all variables in a VAR system can be treated as endogenous. In the model applied, the variables used were $N C 1, L R, P M$, 
and the dummies $C R D, C D, S I Z E$ and $C$ (crisis being considered and fixed as exogenous), in this order. In a second model estimation, we used the same explanatory variables but replaced $N C 1$ with $N C 2$. Moreover, we tried to check if with fewer variables (excluding $C D, S I Z E$, and $C$; by parts) the estimation results would change, as a robustness check. As such, the panel VAR models were estimated using six variables interchangeably. The $C$ dummy is considered exogenous within the setting considering that the $C$ is a macroeconomic variable, exogenous compared to the first five microeconomic variables on firm performance considered.

Panel VAR analysis is predicated upon choosing the optimal lag order in both panel VAR specification and moment condition, which in our case was revealed to be one. The response of $Y_{i, t+s}$ to a one-time impulse in $Y_{i t}$ is described by impulse-response functions (IRFs), with all the other variables held fixed. They can be used to produce the time path of the dependent variables in the VAR, to shocks from all the explanatory variables. If the system of equations is stable, any shock should decline to zero, whereas an unstable system would produce an explosive time path.

Variance decomposition (VD) is useful for examining the effects of shocks to the dependent variables. It determines how much of the forecast error variance for any variable in a system is explained by innovations to each explanatory variable, over a series of time horizons.

The estimation is made using the generalized method of moments (GMM). Firms that obtain more credit from their suppliers are likely to extend more credit to their customers. In this sense, net credit reflects the relative willingness of firms to extend $\mathrm{TC}$, net of the credit that the firms receive themselves (Love et al., 2007; Deloof and La Rocca, 2015).

\section{Results from Panel VAR}

\subsection{GMM panel VAR estimates}

In this section, the estimated results for the panel VAR models are presented and analysed, considering NC1 (Table 3) and NC2 (Table 4). The results show that when using all the variables except $S I Z E$, the exogenous lagged $C$ has a significant negative influence on $N C 1, L R$, and $C D$, but a positive influence on $P M$ (Table 3 ). The signs of the influence remain unchanged when considering SIZE as a variable but $C$ does not seem to influence SIZE in a statistical sense. The negative influence of $C$ on $N C 1$ is consistent with the results found by Tsung-Te and Jian-Hsin (2015), who stated that firms provide less TC during a financial crisis, whereas it contradicts that of Love et al. (2007).

Results from GMM panel VAR estimates denoted that $N C 1$ is significantly positively associated with $N C 1$ lagged and SIZE, and negatively with $C$. The implication of this result is that firms continued to sell to previous years' debtors, respectively buy from previous creditors and hence respected previous selling-buying TC policy, showing that the selected firms provided more than bought on credit. Moreover, larger firms provided more net TC than counterparties, but crises determine a decrease in net TC. 
Table 3 | GMM panel VAR estimates using NC1 and all other variables in the order they appear in the table panels - lag 1

\begin{tabular}{|c|c|c|c|c|c|c|c|}
\hline Dependent $L 1$ : & NC1 & $L R$ & $P M$ & CRD & $C D$ & SIZE & $C$ \\
\hline NC1 & $0.488^{* * *}$ & 0.001 & -0.000 & 0.004 & $-0.015^{*}$ & - & $-0.008^{* *}$ \\
\hline$L R$ & $0.719 * *$ & $0.273^{* * *}$ & -0.001 & 0.093 & -0.038 & - & $-0.075^{*}$ \\
\hline$P M$ & 3.705 & 0.050 & $0.476^{* * *}$ & 0.408 & $1.472^{* *}$ & - & $1.710^{* * *}$ \\
\hline CRD & $-0.398^{* * *}$ & -0.002 & $-0.007^{* * *}$ & $0.170^{* * *}$ & $0.073^{* * *}$ & - & -0.004 \\
\hline$C D$ & -0.041 & -0.000 & $-0.006^{* * *}$ & 0.043 & $0.150 * * *$ & - & $-0.051^{* * *}$ \\
\hline NC1 & $0.488^{* * *}$ & 0.005 & 0.001 & 0.01 & -0.012 & $0.039 *$ & $-0.008^{*}$ \\
\hline$L R$ & 0.476 & $0.046^{* *}$ & -0.011 & -0.038 & $-0.146^{*}$ & $-0.436^{* *}$ & $-0.076^{*}$ \\
\hline$P M$ & 2.847 & 0.124 & $0.511^{* * *}$ & 0.271 & $1.797^{* * *}$ & $4.662^{* * *}$ & $1.870^{* * *}$ \\
\hline$C R D$ & $-0.481^{* * *}$ & -0.003 & $-0.007^{* * *}$ & $0.138^{* * *}$ & 0.051 & -0.111 & -0.014 \\
\hline$C D$ & -0.037 & -0.001 & $-0.007^{* * *}$ & 0.029 & $0.117 * * *$ & $-0.186^{* *}$ & $-0.051 * * *$ \\
\hline SIZE & -0.049 & 0.000 & $0.002^{* *}$ & 0.010 & $-0.028^{*}$ & $0.665^{* * *}$ & 0.005 \\
\hline NC1 & $0.477^{* * *}$ & 0.001 & 0.001 & 0.006 & - & $0.042^{* *}$ & $-0.009^{* *}$ \\
\hline$L R$ & 0.436 & $0.035^{* *}$ & -0.013 & -0.098 & - & $-0.501^{*}$ & -0.056 \\
\hline$P M$ & 2.832 & 0.198 & $0.496^{* * *}$ & 0.703 & - & $5.078^{* * *}$ & $1.854^{* * *}$ \\
\hline$C R D$ & $-0.411^{* * *}$ & -0.004 & $-0.008^{* * *}$ & $0.163^{* * *}$ & - & $-0.124^{*}$ & -0.015 \\
\hline SIZE & -0.081 & 0.001 & $0.003^{* *}$ & 0.010 & - & $0.688^{* * *}$ & 0.007 \\
\hline NC1 & $0.472^{* * *}$ & 0.000 & 0.000 & - & - & - & $-0.010^{* * *}$ \\
\hline$L R$ & $0.694^{* *}$ & $0.265^{* *}$ & -0.006 & - & - & - & $-0.093^{*}$ \\
\hline$P M$ & $3.578^{*}$ & 0.102 & $0.455^{* * *}$ & - & - & - & $1.640^{* * *}$ \\
\hline NC1 & $0.469 * * *$ & -0.001 & -0.000 & -0.005 & - & - & - \\
\hline$L R$ & $0.714^{* *}$ & $0.223^{* *}$ & -0.005 & 0.073 & - & - & - \\
\hline$P M$ & -0.762 & 0.017 & $0.566^{* * *}$ & 0.856 & - & - & - \\
\hline CRD & $-0.273^{* * *}$ & -0.003 & $-0.007^{* * *}$ & $0.200^{* * *}$ & - & - & - \\
\hline NC1 & $0.478^{* * *}$ & 0.001 & 0.001 & 0.006 & - & $0.040^{*}$ & - \\
\hline$L R$ & 0.418 & 0.038 & -0.012 & -0.074 & - & $-0.385^{*}$ & - \\
\hline$P M$ & 0.752 & 0.369 & $0.634^{* * *}$ & 1.158 & - & $5.778^{* * *}$ & - \\
\hline$C R D$ & $-0.393^{* * *}$ & $-0.004^{*}$ & $-0.009 * * *$ & $0.154^{* * *}$ & - & $-0.140 * *$ & - \\
\hline SIZE & -0.081 & 0.001 & $0.002^{* *}$ & 0.000 & - & $0.661^{* * *}$ & - \\
\hline NC1 & $0.477^{* * *}$ & 0.000 & -0.000 & 0.001 & $-0.016^{*}$ & - & - \\
\hline$L R$ & $0.809^{* * *}$ & $0.261^{* * *}$ & -0.004 & 0.103 & -0.050 & - & - \\
\hline$P M$ & -3.454 & 0.205 & $0.576^{* * *}$ & -0.014 & $2.583^{* * *}$ & - & - \\
\hline$C R D$ & $-0.355^{* * *}$ & -0.003 & $-0.007^{* * *}$ & $0.172^{* * *}$ & $0.071^{* * *}$ & - & - \\
\hline$C D$ & $0.118^{*}$ & -0.004 & $-0.008^{* * *}$ & $0.043^{*}$ & $0.117^{* * *}$ & - & - \\
\hline
\end{tabular}

Notes: $L R$ - Liquidity ratio; $P M$ - Profit margin; $C R D$ - Credit dummy; $C D$ - Collection dummy; $C$ - Crisis dummy; NC1 - Net credit 1; L1 stands for lag 1. Instruments: 1(1/4). (NC1 LR PM CRDCDC). ${ }^{*},{ }^{*},{ }^{* * *}$ means statistically significant at $10 \%, 5 \%$ and $1 \%$. In panel VAR all variables are simultaneously exogenous and endogenous, except crisis, which was included in estimations here as an exogenous shock. Unit root tests performed initially proved that all included variables were relevant. The optimal number of lags was selected using the AIC criteria. We control for serial correlation using robust/cluster().

Source: Own elaboration. 
A crisis that occurred in previous years made firms readjust their TC policy and enforced them to increase creditors and decrease debtors (i.e., using more than providing TC). This is also confirmed by the two-sample $t$-test for $N C 1$ and $N C 2$, which generated t-statistics higher than 2, highlighting that firms provided significantly more net $\mathrm{TC}$ in the non-crisis period than in the crisis period. Also, the two-sample $t$-test confirms a $t$-statistic higher than 2 for $P M$, indicating that $P M$ was significantly higher in the crisis period than in the non-crisis period, a result that is in line with the GMM panel VAR estimates using $N C 1$ and $N C 2$.

Our results complement previous studies such as Gonçalves et al. (2016), who found that: firms reduced receivable days during the crisis; firms with low market power increased payable days, and net TC decreased after the crisis occurred. Other results indicate that firms that are financially more exposed to crises extend less TC to their clients (Love et al., 2007); as financing conditions get worse, the more financially exposed firms address TC obtained as an additional form of financing (Coulibaly et al., 2013); more financially constrained firms are more likely to be negatively affected by crises and, thus, are more likely to decrease credit provided and increase credit obtained (Yang, 2011b).

Moreover, the lagged $C$ negatively and significantly affected $L R$ and $C D$, and positively affected $P M$, which means that $C$ in the previous year decreases $L R$ and increases $P M$ of firms. Thus, $C$ makes firms profitable, but not liquid. This was probably the reason for firms to cut the collection period during the crisis in order to increase liquidity. Larger firms were more profitable and less liquid and decreased $C D$ more than counterparties.

Firms that expanded $C D$ in the previous year were affected, having lower $L R$ and higher $P M$ in the present year. Clients were probably motivated by longer collection periods and hence bought more in the present year. However, this was not an easy decision since sales increased but not relative to cash. While using $N C 2, P M$ in the present year is positively and significantly affected by previous year's $L R$. This explains that firms which were more liquid in the previous year were more able to increase $P M$ and provided more than used TC. The positive and significant relationship between $L R$ and $N C 2$ is in line with previous works by Love et al. (2007), who found that more liquid firms offer more credit to their debtors and rely less on credit from their creditors.

We also observe that SIZE exerts a very strong positive influence on $N C 2, P M$, and $S I Z E$, being negative with respect to $C D$ and $L R$. Our results are similar to those of Wilson and Summers (2002), Bougheas et al. (2009), and García-Teruel and Martínez-Solano (2010), who found a positive relationship between SIZE and NC2, and with Berger and Ofek (1995), who found a positive relation between SIZE and PM. Moreover, by including $S I Z E$ into estimations, $C D$ seems to lose statistical significance. When excluding $C D$ from the estimates, $C$ loses significance on $L R$ but the lagged $C$ effect is statistically significant on $N C 2, L R$ (negative for both) and $P M$ when $C R D, C D$, and SIZE are removed from our estimations. Once we remove $C$ as exogenous, lagged SIZE and lagged $C D$ seem to exert statistical influence on $N C 1, P M, C R D$, and $C D$, always keeping the same magnitude of the sign. So, we may infer that $C$ is, in fact, a strong variable to be included in the estimations. 
Table 4 | GMM panel VAR estimates using NC2 and all other variables in the order they appear in the table panels - lag 1

\begin{tabular}{|c|c|c|c|c|c|c|c|}
\hline Dependent $L 1$ : & NC2 & $L R$ & $P M$ & $C R D$ & $C D$ & SIZE & $C$ \\
\hline$N C 2$ & $0.338 * * *$ & 0.001 & -0.002 & -0.017 & -0.007 & - & -0.004 \\
\hline$L R$ & $0.529 * * *$ & $0.354^{* * *}$ & 0.001 & 0.062 & 0.045 & - & $-0.063^{*}$ \\
\hline$P M$ & $5.420 * * *$ & 0.123 & $0.484^{* * *}$ & 0.511 & $1.762^{* * *}$ & - & $1.679 * * *$ \\
\hline CRD & $-0.130 * * *$ & $-0.006^{* *}$ & $-0.007^{* * *}$ & $0.215^{* * *}$ & 0.026 & - & -0.002 \\
\hline$C D$ & $-0.192^{* * *}$ & -0.001 & $-0.006^{* * *}$ & 0.029 & $0.157^{* * *}$ & - & $-0.052^{* * *}$ \\
\hline$N C 2$ & $0.126^{* * *}$ & $0.005^{* *}$ & 0.000 & -0.024 & $0.028^{* *}$ & 0.031 & $-0.011^{* *}$ \\
\hline$L R$ & $0.150^{*}$ & $0.093^{* *}$ & -0.008 & -0.055 & -0.056 & $-0.345^{* *}$ & $-0.079 * *$ \\
\hline$P M$ & 2.650 & $0.257^{* * *}$ & $0.507 * * *$ & 0.253 & $2.375^{* * *}$ & $5.092^{* * *}$ & $1.993 * * *$ \\
\hline CRD & -0.119 & $-0.014^{* * *}$ & $-0.008^{* * *}$ & $0.185^{* * *}$ & -0.030 & $-0.163^{* *}$ & -0.015 \\
\hline$C D$ & -0.050 & $-0.010^{* *}$ & $-0.007^{* * *}$ & 0.012 & $0.082^{* *}$ & $-0.247^{* * *}$ & $-0.055^{* * *}$ \\
\hline SIZE & -0.011 & -0.001 & $0.002^{* *}$ & 0.014 & $-0.041^{* *}$ & $0.655^{* * *}$ & 0.006 \\
\hline NC2 & $0.130 * * *$ & $0.004^{*}$ & -0.000 & -0.015 & - & 0.017 & $-0.010^{*}$ \\
\hline$L R$ & 0.112 & 0.062 & -0.007 & -0.084 & - & $-0.398^{* *}$ & $-0.083^{* *}$ \\
\hline$P M$ & 1.100 & $0.269 * * *$ & $0.486^{* * *}$ & 0.754 & - & $5.478 * * *$ & $1.874 * * *$ \\
\hline CRD & -0.072 & $-0.010^{* *}$ & $-0.007^{* * *}$ & $0.188^{* * *}$ & - & $-0.145^{* *}$ & -0.013 \\
\hline SIZE & -0.000 & 0.000 & $0.003^{* * *}$ & 0.014 & - & $0.692^{* * *}$ & 0.008 \\
\hline$N C 2$ & $0.332^{* * *}$ & -0.000 & -0.002 & - & - & - & -0.016 \\
\hline$L R$ & $0.777^{* * *}$ & $0.359 * * *$ & -0.004 & - & - & - & $-0.083^{* *}$ \\
\hline$P M$ & $3.315^{* * *}$ & 0.180 & $0.443^{* * *}$ & - & - & - & $1.687^{* * *}$ \\
\hline$N C 2$ & 0.052 & 0.006 & $-0.003^{* *}$ & -0.023 & - & - & - \\
\hline$L R$ & $0.909 * * *$ & $0.390 * * *$ & -0.004 & 0.093 & - & - & - \\
\hline$P M$ & $-5.772 * * *$ & 0.216 & $0.564^{* * *}$ & 0.547 & - & - & - \\
\hline CRD & $-0.117^{* * *}$ & $-0.007^{* *}$ & $-0.007^{* * *}$ & $0.212^{* * *}$ & - & - & - \\
\hline$N C 2$ & $0.158 * * *$ & 0.002 & -0.001 & -0.022 & - & 0.002 & - \\
\hline$L R$ & $0.204^{*}$ & 0.053 & -0.011 & -0.105 & - & $-0.392^{* *}$ & - \\
\hline$P M$ & 1.125 & $0.443^{*}$ & $0.659 * * *$ & 1.351 & - & $6.634^{* * *}$ & - \\
\hline CRD & -0.142 & $-0.010^{* *}$ & $-0.009^{* * *}$ & $0.175^{* * *}$ & - & $-0.166^{* *}$ & - \\
\hline SIZE & -0.016 & -0.001 & $0.002^{* *}$ & 0.005 & - & $0.660 * * *$ & - \\
\hline$N C 2$ & 0.015 & 0.006 & $-0.003^{* *}$ & $-0.042^{* *}$ & $0.034^{* *}$ & - & - \\
\hline$L R$ & $0.752^{* * *}$ & $0.315^{* * *}$ & -0.004 & 0.049 & -0.024 & - & - \\
\hline$P M$ & $-5.567 * * *$ & $0.300^{*}$ & $0.599 * * *$ & 0.158 & $2.874^{* * *}$ & - & - \\
\hline CRD & $-0.122^{* * *}$ & $-0.008^{* *}$ & $-0.007^{* * *}$ & $0.206^{* * *}$ & 0.026 & - & - \\
\hline$C D$ & 0.027 & -0.005 & $-0.008^{* * *}$ & 0.028 & $0.128 * * *$ & - & - \\
\hline
\end{tabular}

Notes: $L R$ - Liquidity ratio; $P M$ - Profit margin; CRD - Credit dummy; $C D$ - Collection dummy; $C$ - Crisis dummy; NC2 - Net credit 2; L1 stands for lag 1. Instruments: 1(1/4) (NC2 LRPM CRD CDC). ${ }^{*}, * * * * *$ means statistically significant at $10 \%, 5 \%$ and $1 \%$. In panel VAR all variables are simultaneously exogenous and endogenous, except crisis, which was included in estimations here as an exogenous shock. Unit root tests performed initially proved that all included variables were relevant. The optimal number of lags was selected using the AIC criteria. We control for serial correlation using robust/cluster().

Source: Own elaboration. 
By comparing results from Table 3 and 4, with respect to the panel VAR model results in terms of coefficients and statistical significance for both models, we see that, in general, variables have similar explanatory power when using $N C 1$ or $N C 2$ variables. However, we obtain different estimates whenever the variable of interest changes.

When not considering SIZE, only lagged net TC influences net TC positively, while $C$ loses significance when compared with $N C 1$. In terms of $L R$, the results are similar in both tables, because lagged TC (1 and 2) and $L R$ have positive significant influence on $L R$ and the exogenous $C$ a negative statistical effect. When we turn attention to $P M$, excluding SIZE from the estimations, lagged $N C 2$ influences it positively, whereas we have no statistical significance using $N C 1$. Also lagged $P M, C D$ and $C$ exert a positive influence on $P M$ using both $N C 1$ and $N C 2$.

Almost all the variables influence $C R D$ except $L R$ using $N C 1$ and $C$ (using $N C 1$ and $N C 2$ ), and with respect to $C D$, we have a negative significant influence of $N C 2$ using it, lost when we considered $N C 1$. Using all the seven variables in the estimations, we obtain higher statistical significance when using $N C 2$ with only $P M$ and $C R D$, SIZE not being statistically significant. Considering $P M$ under $N C 2$, only lagged $N C 2$ and $C R D$ reveal to be statistically insignificant, while we also have a negative statistical influence of SIZE and $L R$ on $C R D$, not revealed in $N C 1$, whereas we lose the statistical significance of lagged $N C 2$ on $C R D$, having it in $N C 1$, with a negative sign in both.

Moreover, while using SIZE in the estimations, and considering $N C 2, L R$ exerts a negative influence on $C D$, which we do not have, at least with significance, using $N C 1$. The lagged variables $P M$ and SIZE in a positive sense and $C D$ (negative) have statistical significance in explaining SIZE considering both $N C 1$ and $N C 2$.

Considering the results in Table 4, when removing $C D$ from estimates, SIZE loses significance on $N C 2$ but $L R$ now seems to reveal a positive influence on $N C 2$ as in the case of Emery (1984) and Rajendra (2011). However, exogenous $C$ appears now with significant and negative influence on $L R$, whereas lagged $L R$ loses it when compared to the results in Table 3 under $N C 1$. In general, it seems that when including SIZE and excluding $C D$, the lagged $L R$ reveals statistical significance on the other variables, meaning it has an explanatory capacity. When removing $C R D, C D$, and SIZE, $C$ loses its significance when using $N C 2$ when compared to $N C 1$, but also with a negative sign. However, when we exclude $C D, S I Z E$, and $C$, only $P M$ is statistically significant on $N C 2$ where only lagged $N C 1$ was, considering $N C 1$. In this case, also $N C 2$ reveals to influence $P M$ negatively and significantly, while also lagged $L R$ influences $C R D$ under $N C 2$ in a negative and statistical sense. We should also notice that in Table 3, this was the only variable not revealing statistical significance.

Overall, the results seem to be sensitive to the choice of the net TC variable with respect to statistical significance, although with similar sign magnitudes under $N C 1$ or $N C 2$. In both, the results suggest the importance of including both SIZE and $C$ into estimations. An interesting finding is that net TC is positively and significantly influenced by itself from the previous year. One possible explanation can be due to effects of accrual accounting. Goods are delivered and/or services are performed in the previous year, but money is collected and/or paid in the current year. While debtors/creditors affect the next coming year, assets are used in operations and sales are recorded in the current year. 


\subsection{Granger causality test results under panel VAR}

The study continues using panel VAR Granger causality approaches considering the estimations of panel VAR models with six (excluding SIZE) and with seven (including SIZE) variables. When we do not consider SIZE, $N C 1$ and $N C 2$ Granger cause liquidity, while only $C D$ Granger causes $N C 1$. Moreover, $N C 2$ Granger causes $P M$ while both $N C 1$ and $N C 2$ Granger cause $C R D$. $C R D$ is also Granger-caused by $P M$, while only Granger-caused by $C D$ (in $N C 1$ ) and by $L R$ (under $N C 2$ ). In fact, the results reveal a bidirectional causality between $P M$ and $C D$ but only a unidirectional one running from $N C 2$ to $C D$ (Table A1).

When considering SIZE in the Granger causality tests, we observe from the data a unidirectional causality running from SIZE to $N C 1$, from $C D$ to $L R$ using $N C 1$, from SIZE to $L R$ and from $N C 1$ and $P M$ to $C R D$. There seems to exist a bidirectional causality between $C D$ and $P M$, between SIZE and $P M$ and between SIZE and $C D$. When considering $N C 2$, there seems to exist bidirectional causality between $L R$ and $N C 2$, between $C D$ and $P M$, between SIZE and $P M$ and between SIZE and $C D$. However, there is only a unidirectional Granger causality running from $C D$ to $N C 2$, from $S I Z E$ to $L R$, from $L R$ to $P M$, from $L R$ to $C R D$, from $P M$ to $C R D$, from SIZE to $C R D$ and from $L R$ to $C D$. These results make evident the dynamic interactions among the variables under study, thus justifying their simultaneous use.

\subsection{Forecast-error variance decomposition and impulse-response functions using net trade credit}

Our results show that all the variables' own impact decreases as time goes (the forecasting horizon increases) and their variance is mostly explained by shocks in the variables themselves. However, own explanatory capacity is lower in percentage terms when we use $N C 2$, except for $C$ and $C D$ (Table A2), meaning that the other variables in the model have a higher explanatory capacity or are able to explain more when using $N C 2$.

When including SIZE (Table A2), own explanatory capacity is lower in percentage terms when we use $N C 1$, except for SIZE, meaning that by including SIZE, the other variables in the model have a higher explanatory capacity or are able to explain more when using $N C 1$.

Considering only net trade credit, $L R, P M, C R D, C D$ and $C$ (crisis being exogenous, the results would not appear in the FEVD tables), we see that $C D$ is able to explain $0.2 \%$ of the forecasting error variance of $N C 1$, while $P M 0.3 \%$ and $C R D 0.1 \%$ of $N C 2$ in longterm horizons. Both $N C 1$ and $N C 2$ are able to explain more of $L R$ (around $2 \%$ ), while $N C 1$, $N C 2$ (more in this case) and $C D$ are the variables that can tell more about the percentage of the fluctuation in $P M$, with a better explanation as time goes. In terms of $C R D$, both $N C 1$ and $N C 2$ and $P M$ explain more of its forecasting error variance, while for $C D$ the higher explanatory capacity is attributable to net TC (more in NC1) and $C R D$, followed by $P M$.

As for the results of the estimations when including SIZE (Table A3), we observe that variables gain higher explanatory capacity on the response variables and that SIZE has higher explanatory capacity on $N C 1$ (2.4\% at 10 years' horizon), on $N C 2(0.2 \%)$, on $L R$ 
(around $0.4 \%$ ), on $P M$ in long-term horizons (up to $7.3 \%)$, on $C(2.8 \%$ and $3.1 \%$ for $N C 1$ and $N C 2$, respectively, at 10 years of forecasting horizon) and also on $C D(3.6 \%$ and $5.1 \%$, respectively for $N C 1$ and $N C 2$ ). However, it explains $2.5 \%$ and $2.4 \%$ of the fluctuation in SIZE for $N C 1$ and $N C 2$. Besides SIZE, $P M$ seems to explain more of $N C 1$ fluctuations, while $L R$ and $C D$ explain more of $N C 2$ fluctuations.

$L R$ is mostly explained by $N C 1$ and $N C 2$ and by SIZE, while fluctuations in $P M$ depend more on $N C 1, N C 2, S I Z E$, and $C D$ in this order, meaning that SIZE explains more in $N C 1$ and $C D$ in $N C 2$. $C R D$ fluctuations are mostly explained by shocks in $N C 1$ and $P M$, while the results reveal that using $N C 2$, the $L R$ and $P M$ are more able to explain changes occurring in $C R D$. With respect to $C D, C R D, N C 2$, and $P M$, in this order, are able to justify more of its fluctuations when using $N C 1$, while $C R D$, SIZE, and $P M$ being able to explain more movements in $C D$, in this order, when $N C 2$ is used.

Analysing the IRF plots in both models using $N C 1$ (Figure A1) and $N C 2$ (Figure A2), considering the seven-variable model estimates (including SIZE), the results indicate that a positive shock of SIZE has an initial positive impact on $N C 1$ and an initial positive shock on $N C 2$ and $L R$ when considering $N C 2$.

The impulses of SIZE seem to exert an initial negative and significant impact on $C R D$, $P M$, and $L R$, using $N C 1$, while fading out within five years. It is also negative and significant considering $N C 2$ over $C R D$ and $P M$. Considering $C D$ impulses, these are negative and significant over SIZE and $P M$ in both, and positive and significant over $C R D$ in $N C 1$ and over $N C 2$. $C R D$ shocks exert initial positive influence on $C D$ in $N C 1$ and $N C 2$, and over $L R$ only in $N C 2$. In both $N C 1$ and $N C 2, C R D$ impulses affect $P M$ negatively and significantly.

As for $P M$ impulses, these seem to have a negative initial effect at two years on $C R D$ and $C D$ in $N C 1$ and $N C 2$, thus turning to be positive from three to five years, while being positive and significant over $N C 2$ only. Impulses of $L R$ do not seem to be statistically significant except over $N C 2$, while net TC impulses have a negative and significant effect on SIZE and $C R D$ in $N C 1$ and $P M$ under $N C 2$. It has a positive and significant influence on $C D$ and $L R$ in both models ( $N C 1$ and $N C 2$ ). All these shocks seem to fade out after two to three years, thus making those variables affected by net TC, return to their longterm equilibrium values after these two to three years. Also, the initial effect of $N C 1$ and $N C 2$ on $L R$ is positive and significant, which fades out in approximately two years. The influence of liquidity shocks on NC2 is positive, but in the case of $N C 1$ the results are insignificant, agreeing with the findings of Niskanen and Niskanen (2006) but opposite to those of Bougheas et al. (2009).

\section{Conclusions}

This paper uses a panel VAR approach to analyse the relationship between net trade credit (NC1 and NC2) and variables $P M, L R$, and dummies $C R D, C D$, SIZE, and $C$. It shows that: $N C 2$ is significantly and positively influenced by lagged $N C 2, L R$, and $P M$, whereas negatively and statistically influenced by lagged $C R D$ and $C D$. For both $N C 1$ and $N C 2$, $L R$ has the lowest explanatory capacity; a positive shock of $C$ is positive and significant over $P M$, but a positive shock of $P M$ on $C$ reveals to be positive up to five years. A positive 
shock of $N C 2$ has a negative influence on $C, C D$ and the $C R D$ dummy, although in the last this effect is short-lived.

Our results show that the net TC is obviously affected by crises. We believe that the financial crisis forced firms to redefine their TC policy and thus in the respective period they used less net TC. However, for the whole analysed period firms sold more than having bought on credit, and on average a positive net TC was found. Furthermore, it was proved that the net TC is significantly affected by its own lagged value, $L R, S I Z E$, and $C D$, and should thus be taken into account when firms redefine their TC policies. Moreover, ability to define trade policies in the past, robustness of negotiation, company liquidity situation and size (the higher the better the negotiation ability) will play an important role when redefining trade credit policies, especially during a critical period such as the financial crisis.

For next studies, we believe that the research should be extended by testing whether TC plays a role of substituting for bank credit as done by de Blasio (2005), continuing with testing of Meltzer's (1960) hypothesis and whether trade credit insurance (Sokolovska, 2017) may extend using of TC by firms. Adding other macroeconomic factors that might affect TC policies is also a further avenue of research.

\section{References}

Abrigo, M. R. M., Love, I. (2015). Estimation of Panel Vector Autoregression in Stata: A Package of Programs. University of Hawai'i at Manoa. Working Paper No. 16-2. [Retrieved 2016-11-29] Available at: http://www.economics.hawaii.edu/research/workingpapers/WP_16-02.pdf

Altunok, F. (2012). Three Essays of Trade Credit. North Carolina State University.

Bureau van Dijk (2015). Amadeus Database. Bratislava, Slovakia.

Baños-Caballero, S., García-Teruel, J. P., Martínez-Solano, P. (2014). Working Capital Management, Corporate Performance, and Financial Constraints. Journal of Business Research, 67(3), 332-338, https://doi.org/10.1016/j.jbusres.2013.01.016

Bastos, R., Pindado, J. (2013). Trade Credit During a Financial Crisis: A Panel Data Analysis. Journal of Business Research, 66(5), 614-620, https://doi.org/10.1016/j.jbusres.2012.03.015

Berger, P. G., Ofek, E. (1995). Diversification's Effect on Firm Value. Journal of Financial Economics, 37(1), 39-65, https://doi.org/10.1016/0304-405X(94)00798-6

Biais, B., Gollier, C. (1997). Trade Credit and Credit Rationing. The Review of Financial Studies, 10(4), 903-937, https://doi.org/10.1093/rfs/10.4.903

Bougheas, S., Mateut, S., Mizen, P. (2009). Corporate Trade Credit and Inventories: New Evidence of a Trade-off from Accounts Payable and Receivable. Journal of Banking \& Finance, 33(2), 300-307, https://doi.org/10.1016/j.jbankfin.2008.07.019

Burkart, M., Ellingsen, T. (2004). In-Kind Finance: A Theory of Trade Credit. American Economic Review, 94(3), 569-590, https://doi.org/10.1257/0002828041464579

Cheng, N. S., Pike, R. (2003). The Trade Credit Decision: Evidence of UK Firms. Managerial and Decision Economics, 24(6-7), 419-438, https://doi.org/10.1002/mde.1049

Choi, W. G., Kim, Y. (2005). Trade Credit and the Effect of Macro-Financial Shocks: Evidence from U.S. Panel Data. Journal of Financial and Quantitative Analysis, 40(4), 897-925, https://doi.org/10.1017/s0022109000002027 
Coulibaly, B., Sapriza, H., Zlate, A. (2013). Financial Frictions, Trade Credit, and the 2008-09 Global Financial Crisis. International Review of Economics and Finance, 26, 25-38, https://doi.org/10.1016/j.iref.2012.08.006

Cull, R., Xu, C. L., Zhu, T. (2009). Formal Finance and Trade Credit during China's Transition. Journal of Financial Intermediation, 18(2), 173-192, https://doi.org/10.1016/j. jfi.2008.08.004

Cuñat, V. (2007). Trade Credit: Suppliers as Debt Collectors and Insurance Providers. Review of Financial Studies, 20(2), 491-527, https://doi.org/10.1093/rfs/hhl015

Cuñat, V., Garcia-Appendini, E. (2012). Trade Credit and its Role in Entrepreneurial Finance, in Cuñat, V. G.-A., Cumming, D., eds., Oxford Handbook of Entrepreneurial Finance. New York: Oxford University Press, pp. 526-557, https://doi.org/10.1093/ oxfordhb/9780195391244.013.0018

de Blasio, G. (2005). Does Trade Credit Substitute for Bank Credit? Evidence from Firm-Level Data, Economic Notes, 34(1), 85-112, https://doi.org/10.1111/j.0391-5026.2005.00145.x

Delannay, A. F., Weill, L. (2004). The Determinants of Trade Credit in Transition Countries. Economics of Planning, 37(3-4), 173-193, https://doi.org/10.1007/s10644-005-5062-9

Deloof, M., La Rocca, M. (2015). Local Financial Development and the Trade Credit Policy of Italian SMEs. Small Business Economics, 44(4), 905-924, https://doi.org/10.1007/ s11187-014-9617-x

Emery, G. (1984). A Pure Financial Explanation for Trade Credit. Journal of Financial and Quantitative Analysis, 19(3), 271-285, https://doi.org/10.2307/2331090

Eurostat (2015). Construction Statistics - NACE Rev. 2. [Retrieved 2016-10-12] Available at: http://ec.europa.eu/eurostat/statistics-explained/index.php/ Construction_statistics_-_NACE_Rev._2

Ferrando, A., Mulier, K. (2013). Do Firms Use the Trade Credit Channel to Manage Growth? Journal of Banking and Finance, 37(8), 3035-3046, https://doi.org/10.1016/j. jbankfin.2013.02.013

Ferris, J. (1981). A Transactions Theory of Trade Credit Use. Quarterly Journal of Economics, 96(2), 243-270, https://doi.org/10.2307/1882390

Fisman, R., Love, I. (2003). Trade Credit, Financial Intermediary Development and Industry Growth. Journal of Finance, 58(1), 353-374, https://doi.org/10.1111/1540-6261.00527

García-Teruel, P. J., Martínez-Solano, P. (2010). Determinants of Trade Credit: A Comparative Study of European SMEs. International Small Business Journal, 28(3), 215-233, https://doi. org/10.1177/0266242609360603

Gonçalves, A. B., Schiozer, R., Sheng, H. H. (2016). Trade Credit during Financial Crisis: Do Market Power and Financial Constraints Matter? [Retrieved 2016-11-17] Available at: http://doi.org/10.2139/ssrn.2723504

Hill, M. D., Kelly, G. W., Lockhart, G. B., Washam, J. O. (2010). Trade Credit, Market Value, and Product Market Dynamics. New York: FMA.

Kohler, M., Britton, E., Yates, T. (2000). Trade Credit and the Monetary Transmission Mechanism. Bank of England. London Working Paper No. 115, https://doi.org/10.2139/ssrn.234693

Lang, L. H., Stulz, R. M. (1994). Tobin's q, Corporate Diversification, and Firm Performance. Journal of Political Economy, 102(6), 1248-1280, https://doi.org/10.1086/261970

Love, I., Ziccino, L. (2006). Financial Development and Dynamic Investment Behavior: Evidence from Panel VAR. The Quarterly Review of Economics and Finance, 46(2), 190-210, https://doi.org/10.1016/j.qref.2005.11.007 
Love, I., Preve, L. A., Sarria-Allende, V. (2007). Trade Credit and Bank Credit: Evidence from Recent Financial Crises. Journal of Financial Economics, 83(2), 453-469, https://doi.org/10.1016/j.jfineco.2005.11.002

Marotta, G. (2005). When do Trade Credit Discounts Matter? Evidence from Italian Firm-level Data. Applied Economics, 37(4), 403-416, https://doi.org/10.1080/0003684042000329063

Martínez-Sola, C., García-Teruel, J. P., Martínez-Solano, P. (2014). Trade Credit and SME Profitability. Small Business Economics, 42(3), 561-577, https://doi.org/10.1007/ s11187-013-9491-y

Masanori, O. (2001). Determinants of Trade Credit in the Japanese Manufacturing Sector. Journal of the Japanese and International Economies, 15(2), 160-177, https://doi. org/10.1006/jjie.2001.0466

McGuinness, G., Hogan, T. (2016). Bank Credit and Trade Credit: Evidence from SMEs Over the Financial Crisis. International Small Business Journal, 34(4), 412-445, https://doi.org/10.1177/0266242614558314

Meltzer, A. (1960). Mercantile Credit, Monetary Policy, and Size of Firms. Review of Economics and Statistics, 42(4), 429-437, https://doi.org/10.2307/1925692

Ng, K. C., Smith, J. K., Smith, L. R. (1999). Evidence on the Determinants of Credit Terms Used in Interfirm Trade. The Journal of Finance, 54(3), 1109-1129, https://doi. org/10.1111/0022-1082.00138

Niskanen, J., Niskanen, M. (2006). The Determinants of Corporate Trade Credit Policies in a Bank-Dominated Financial Environment: The Case of Finnish Small Firms. European Financial Management, 12(1), 81-102, https://doi.org/10.1111/j.1354-7798.2006.00311.x

Petersen, M. A., Rajan, R. G. (2007). Trade Credit: Theories and Evidence. Review of Financial Studies, 10(3), 661-669, https://doi.org/10.1093/rfs/10.3.661

Rajendra, V. R. (2011). The Determinants of Trade Credit: Evidence from Indian Manufacturing Firms. Mumbai Working Papers No. 012.

Santos, G. A., Sheng, H. H., Bortoluzzo, A. (2012). The Use of Trade Credit by Firms: Evidence for Latin America. Insper Instituto de Ensino e Pesquisa.

Seifert, D., Seifert, R. W., Protopappa-Sieke, M. (2013). A Review of Trade Credit Literature: Opportunities for Research in Operations. European Journal of Operational Research, 231(2), 245-256, https://doi.org/10.1016/j.ejor.2013.03.016

Smith, J. K. (1987). Trade Credit and Informational Asymmetry. The Journal of Finance, 42(4), 863-872, https://doi.org/10.1111/j.1540-6261.1987.tb03916.x

Sokolovska, O. (2017). Trade Credit Insurance: Theoretical Background and International Practices. Scientific Annals of Economics and Business, 64(1), 123-137, https://doi.org/10.1515/saeb-2017-0008

Tsung-Te, L., Jian-Hsin, C. (2015). Trade Credit and Bank Loan: Evidence from Chinese firms. International Review of Economics \& Finance, 36, 17-29, https://doi.org/10.1016/j. iref.2014.11.004

Tsuruta, D. (2015). Bank Loan Availability and Trade Credit for Small Businesses During the Financial Crisis. The Quarterly Review of Economics and Finance, 55(C), 40-52, https://doi.org/10.1016/j.qref.2014.09.004

Wilner, B. (2000). The Exploitation of Relationships in Financial Distress: The Case of Trade Credit. The Journal of Finance, 55(1), 153-178, https://doi.org/10.1111/0022-1082.00203 
Wilson, N., Summers, B. (2002). Trade Credit Terms Offered by Small Firms: Survey Evidence and Empirical Analysis. Journal of Business Finance \& Accounting, 29(3-4), 317-351, https://doi. org/10.1111/1468-5957.00434

Wu, W., Ruai, O. M., Wu, C. (2012.). Trade Credit, Cash Holdings, and Financial Deepening: Evidence from a Transitional Economy. Journal of Banking and Finance, 36(11), 2868-2883, https://doi.org/10.1016/j.jbankfin.2011.04.009

Yang, X. (2011). Trade Credit versus Bank Credit: Evidence from Corporate Inventory Financing. The Quarterly Review of Economics and Finance, 51(4), 419-434, https://doi.org/10.1016/j. qref.2011.07.001 